\title{
Adenosarcoma pM1 TNM Finding v7
}

National Cancer Institute

\section{Source}

National Cancer Institute. Adenosarcoma pM1 TNM Finding v7. NCI Thesaurus. Code C89627.

Distant metastasis (excluding adnexa, pelvic and abdominal tissues). (from AJCC 7th Ed.) 